\title{
Analysis of Tourist Travel Pattern for Youth Travel Segment in Ambon Island
}

\author{
Tassya Yuliani Simasima ${ }^{1 *}$, Vitria Ariani $^{2}$, Rahmat Ingkadijaya $^{3}$ \\ 1,3 Sekolah Tinggi Pariwisata Trisakti \\ ${ }^{2}$ Universitas Bina Nusantara \\ *tassya.simasima@gmail.com
}

\begin{abstract}
This study aimed to identify The Youth Travel Characteristic, The Youth Travel Pattern and The Model of Youth Travel Pattern Development in Ambon island. This study used descriptive methods approach. Mean and frequencies are for analyzing respondents' characteristics. Travel Pattern was analyzed by using GIS software. SWOT analysis was used to develop the Travel Pattern Model. The respondents were 100 youth travels at the age between 15 years - 30 years who visited Ambon City. The research sampling technique was convenience sampling. The questionnaires were distributed between June 2017 - July 2017. This study found that youth travelers who visited Ambon Island was dominated by young local tourists, under 26 years old, well educated, searched for cultural and social values. The main information sources during the trip were from friends or internet and they tend to plan their travel independently or with their family and friends rather then using travel agencies. The main trip driver is outdoor with leisure activities on the beach. This study also found out that security was the most influencing factor in determining travel itinerary of youth traveler. During the trip in Ambon Island, youth traveler was formed five travel pattern. The most travel pattern was formed by youth traveler was a single point. The study developed four youth travel pattern models to incrase the number of youth traveler visiting Ambon Island.
\end{abstract}

Keywords: Travel Pattern, Youth Travel, Ambon Island.

TRJ Tourism Research Journal, Volume 1 (1), 2017 


\section{A. Introduction}

Youth Travel are known as Millennial Travel. It's for youth tourists who were born in the 80s and early 90s (CTC, 2015). In 2010, youth travel generated US $\$ 165$ billion in tourism receipts and 187 million international visited around the world. It's 20\% of total global travel (CTC, 2015; UNWTO 2011). The research that was conducted by WYSE and UNTWO (2011) showed that Youth Travel was growing very rapidly in the last decade and had started to leave its original status as niche market. The global youth travel industry is estimated to represent almost 190 million international trips a year, and the youth travel industry has grown faster than global travel overall. By 2020 there will be almost 300 million international youth trips per year.

One of the destinations in Maluku Province that has potential as a youth travel destination is Ambon Island. There are various types of attraction that can be a choice for youth traveler in Ambon Island, such as natural attractions, cultural attractions, historical site and culinary. As the capital city of Maluku Province and the main entrance on the Ambon Island. Every year there is a significant increase of tourist arrivals in Ambon City. According to recent report from Ministry of Tourism in Ambon City, there are 25.475 domestic and 7.436 international tourists' arrivals in Ambon City. It's higher than the number of domestic and international tourists' arrivals in 2015. However, based on the number of tourists' arrivals, according to tour operator in Ambon City AyoBarondaTrip (2017) there are only about $15 \%$ of tourists at the age of 15-30 years old who visited the Ambon Island. This shows that the interest of youth travelers to visit Ambon Island is still low. The owner of AyoBarondaTrip (2017) revealed that one of the causes is the lack of choice of travel patterns that suit to the interest of youth travelers. The Existing travel patterns are not yet considered as the right target for youth travel.

From the background, this study aims are: 1) to identify the youth travel characteristic in Ambon Island, 2) to identify the existing travel pattern of the youth travel in Ambon Island, and 3) to recommend the model of youth travel pattern in Ambon Island.

\section{B. Literature Review}

\section{Travel Pattern}

The travel pattern is the structure, the framework, and the travel path from one point of destination to another interconnected destinations containing information about facilities, activities, and services that provide travel options for industry and individual travelers to influence decision making in their trip. The more varied the travel pattern offered is expected to increase the interest of tourists to travel in Indonesia (Kemenpar, 2015). 
Research from Gigi Lau and Bob Mckercher (2006) in his journal entitled Undestanding Tourist Movement Patterns in a destination: A GIS Approach describes the Travel Pattern category in Table 1.

Table 1 Youth Travel Pattern

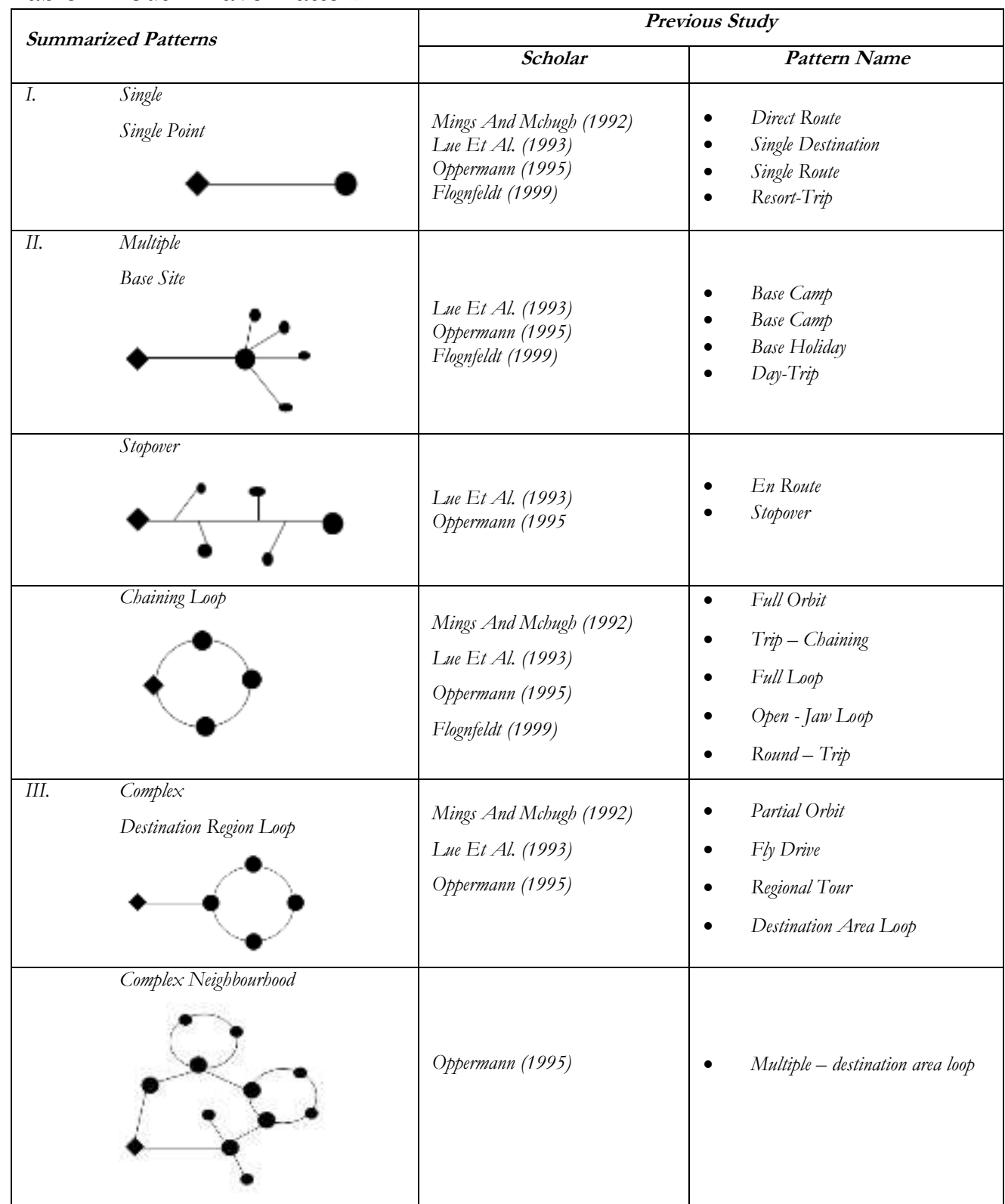

Source : Gigi Lau and Bob Mckercher (2006)

Single Point: Tourists visit a single destination and return home using the same route.

Base Site: Tourist starts from home and travels to a primary destination, then visits to secondary destinations within that particular area. 
Stopover: There is a single destination as the main focus of the trip where attractions or destinations along the route are present. Tourists are normally captured by these attractions either on their way to the main destination or on their way back.

Chaining Loop: Tourists go through several destinations without any repetition. Stops in between the loop may not necessarily be related to or connected to each other. Tourists visit places or attractions in connection with the destination to which they are travelling.

Complex Destination- Region Loop: Tourists travel part of their trip over a direct route to either a primary destination or a site near the destination region, and from there start a circuitous route visiting other destinations. After finishing the touring loop, they return home through the most direct route between the primary destination and home.

Complex Neighborhood: Tourists are going from one destination to the other destination, without repeating the travelling leg, may travel to a number of attractions or places within a region. This pattern can be seen as a combination of some or all patterns mentioned above. This is a pattern that is most suitable to describe the complexity of tourist movement patterns, allowing variations and blending of different patterns.

Generally before traveling, tourists will make a travel itinerary. According to Suyitno (2001), itinerary is a document that can be used to illustrate the conduct of a travel tour. According to Education Bureau Hongkong in the book Tourism and Hospitality Studies Five tuned version (2013), there are some considerations to create an itinerary. They're preferences and tourist needs, interest or motivation of tourists, budget travel, and security.

\section{Youth Travel}

The word "Youth" is defined by United Nations as their category between 15 Years and 24 Years. UNWTO (2008) states that Youth travel includes all independent trips for periods of less than one year by people aged 16-29 which are motivated, in part or in full, by a desire to experience other cultures, build life experience and or benefit from formal and informal learning opportunities outside one's usual environment. In 2010, UNWTO stated that the traditional age of youth traveler had shifted to 15-30 years old.

Youth Travel has values of life experience. In a 2010, poll conducted in Canada, nearly half of Youth Travel considered travel as one of the most important aspects of their lives, higher than any other age segment. For youth travel, travel is more than a vacation and an important component of their growth and self-learning process. Youth travel tends to embrace social values, innovation, and environmental conciousness. Youth travel also tends to make a travel as a motivation to "Show Off". They prefer to explore the culture and authentic experience. They need something unique and can express themselves and tend to choose local brands. (CTC, 2015)

TRJ Tourism Research Journal, Volume 1 (1), 2017 
A study by Richards (2007) found that youth travel very sensitive to price, so the price is an important element that $94.3 \%$ influence them in making travel arrangements. Climate is also one of the main factors and becomes an important attribute in a tourism destination ( $\mathrm{Hu} \&$ Ritchie, 1993). The time when youth travels get the best price to make a trip becomes the main criteria in choosing travel time. They also choose the time when they can get the day off from school or their work, the availability of their friends and the best time to visit the places they want to visit. Research conducted by the Canadian Tourism Commission (2015) revealed that the majority of young travelers plan their trips through online booking. While Travel Agent is usually used to order Tours, insurance and others (Demeter et al, 2015).

The travel patterns and the behavior of young travelers are different from other age segments, especially in terms of trip purpose and destination visited. The main trip drivers for youth travel to make a trip are outdoor, culture, spectator sports, theme parks, historic sites/ buildings, culinary, shopping. Their favorite activities are eat and drink local food and beverage, visit popular tourist attractions, visit cultural attractions, relax on a beach, meet local people, visit family or friends, attend events and festivals, get off the beaten track, hiking/trekking (CTC, 2015).

Even though it is not the main target, the duration of youth travels is generally higher, but varies according to place of origin or province of origin of youth travels (Canadian Tourism Commission (2015). Kihara (2009) explains that in tourism the average length of stay is generally a few days (3-4 days).

\section{SWOT Analysis}

Freddy Rangkuti (2016) explains that the SWOT Analysis is a systematic identification of various factors to formulate the company's strategy. This analysis is based on logic that can maximize strengths and opportunities, while simultaneously minimizing weaknesses and threats. The strategy decision-making process is always concerned with the development of corporate mission, goals, strategies and policies. Thus, strategic planning should analyze the company's strategic factors (strengths, weaknesses, opportunities and threats) in the current conditions. 


\section{Framework}

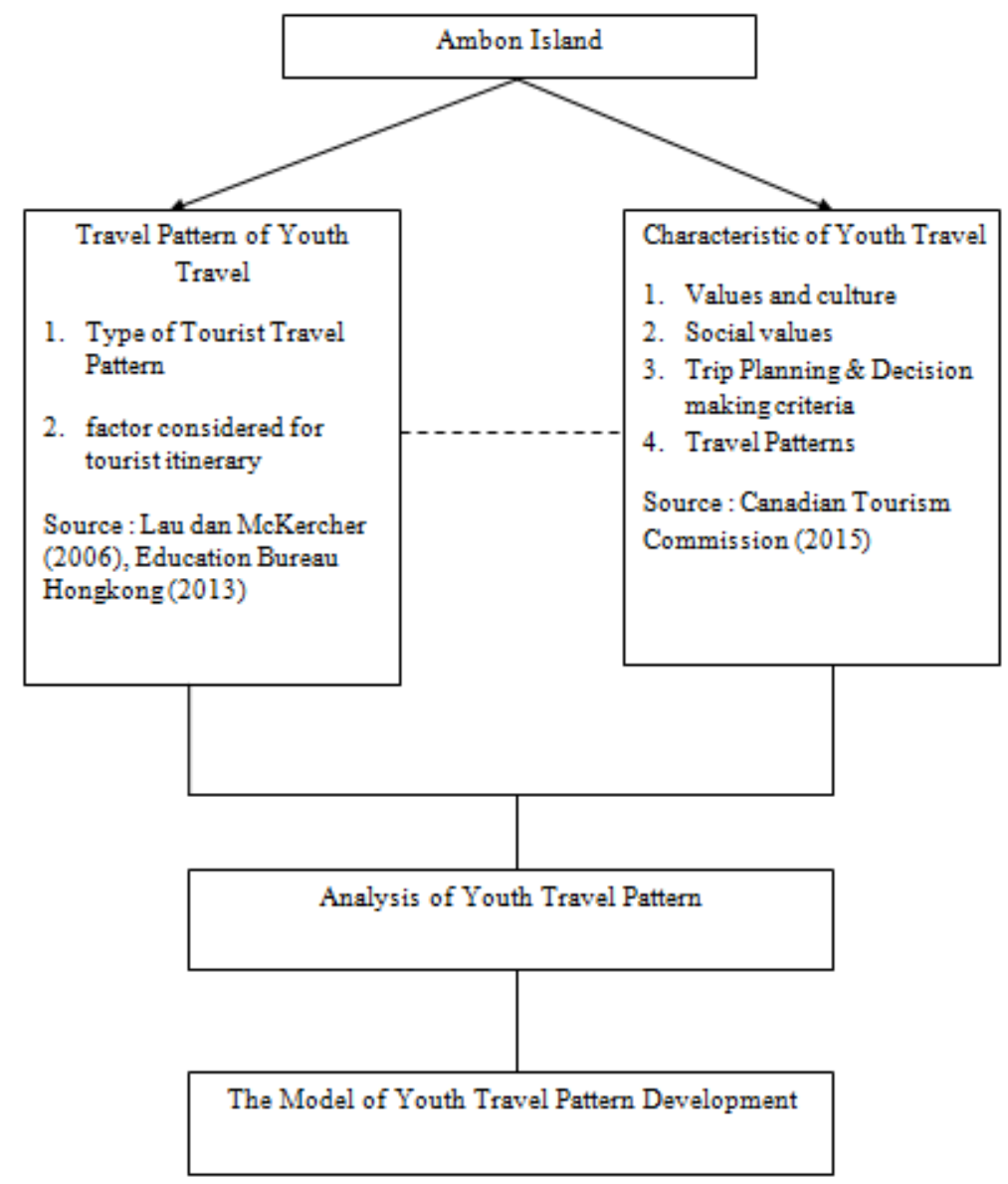

Figure 1 Framework

Source: The rresults of data processing (2017)

\section{Research Methodology}

The population was the number of tourists who visited Ambon City in 2016. It's around 32,991 people (Source: Tourism Department Ambon City, 2017). The respondents were 100 youth travels at the age between 15 years - 30 years. The research sampling technique was convenience sampling, that tried to get a sample based on the availability of elements and the ease of obtaining it (Sugiarto et al., 2015). The questionnaires were distributed between June 2017 July 2017.

The data was collected by distributing questionnaire to respondents. The questionnaire consistted of three sections. The first section aimed to gather the demographic background of each respondent. The second section related to the charachteristic of youth travel. The third section related to the travel pattern of 
youth travel in Ambon Island. The variable was measured by using Likert scale from 1 to 5 (strongly disagree to strongly agree).

This study used descriptive methods approach. Mean and frequencies are for analyzing respondents' demographic and perception. They were analyzed by using SPSS 21. Travel Pattern was analyzed by using. GIS software. SWOT analysis was used to gather the Travel Pattern Model recommendation.

\section{Result and Discussion}

\section{Demographic}

The demographic data of the respondent are shown at Table 2. It consists of gender, age, educational level, employment, income per month, frequency of visit, source of holiday money, and the origin of youth traveler. According to the data on table 2, youth travel who visited Ambon island dominated by female traveler at the age between 23 years to 26 years and 19 years to 22 years.

The majority of the youth traveler are students who come from East Seram (SBT) and have high level education. The study found that 50 respondents had a monthly income of Rp. 1.000 .000 or less and 43 Respondent had a monthly income between Rp. 1.000.000 - Rp. 6.000.000 and their trip was financed by personal savings.

The average frequency of youth travel arrivals to Ambon Island has been more than 3 times a trip that is dominated by local tourist from the other region in Maluku Province. The increasing frequency of visits is due to youth travels tend to have a lot of time compared to other age segments. with much time they have got them to travel more often and spend a lot of time in visited tourist destinations (Canadian Tourism Commission, 2015; Moisa, 2010). 
Tabel 2. Demographic of 100 Respondents

\begin{tabular}{|c|c|c|c|c|c|c|}
\hline \multirow[t]{2}{*}{ Category } & \multicolumn{5}{|c|}{ Origin } & \multirow[t]{2}{*}{ Total } \\
\hline & $\begin{array}{l}\text { Maluku } \\
\text { Tengah }\end{array}$ & SBB & SBT & $\begin{array}{l}\text { Other Region } \\
\text { in Maluku }\end{array}$ & $\begin{array}{l}\text { Other City in } \\
\text { Indonesia }\end{array}$ & \\
\hline \multicolumn{7}{|l|}{ Gender } \\
\hline Male & 12 & 1 & 13 & 8 & 10 & 44 \\
\hline Female & 8 & 1 & 19 & 11 & 17 & 56 \\
\hline \multicolumn{7}{|l|}{ Age (year) } \\
\hline $15-18$ & 1 & 0 & 6 & 3 & 3 & 13 \\
\hline $19-22$ & 9 & 0 & 14 & 4 & 6 & 33 \\
\hline $23-26$ & 8 & 2 & 10 & 9 & 14 & 43 \\
\hline $27-30$ & 2 & 0 & 2 & 3 & 4 & 11 \\
\hline \multicolumn{7}{|l|}{ Educational Level } \\
\hline Under Senior High School & 0 & 0 & 1 & 1 & 1 & 3 \\
\hline Senior High School & 8 & 1 & 20 & 6 & 11 & 46 \\
\hline Diploma $1 / 2 / 3$ & 2 & 0 & 3 & 5 & 0 & 10 \\
\hline Bachelor & 9 & 1 & 7 & 7 & 15 & 39 \\
\hline Master & 1 & 0 & 1 & 0 & 0 & 2 \\
\hline \multicolumn{7}{|l|}{ Employment } \\
\hline Student & 6 & 0 & 22 & 7 & 9 & 44 \\
\hline Public servants & 2 & 0 & 1 & 1 & 0 & 4 \\
\hline Employees in private sector & 5 & 1 & 5 & 5 & 6 & 22 \\
\hline Entrepreneur & 4 & 0 & 3 & 2 & 4 & 13 \\
\hline Others & 3 & 1 & 1 & 4 & 8 & 17 \\
\hline \multicolumn{7}{|l|}{ Income per month } \\
\hline$<$ Rp. 1.000 .000 & 8 & 0 & 21 & 10 & 11 & 50 \\
\hline Rp. $1.000 .000-$ Rp. 6.000 .000 & 10 & 2 & 11 & 9 & 11 & 43 \\
\hline Rp. 6.000 .001 - Rp. 12.000 .000 & 2 & 0 & 0 & 0 & 5 & 7 \\
\hline \multicolumn{7}{|l|}{ Frequency of visit } \\
\hline $1 \mathrm{st}$ & 0 & 1 & 8 & 1 & 11 & 21 \\
\hline 2nd & 1 & 0 & 2 & 1 & 7 & 11 \\
\hline $3 r d$ & 1 & 0 & 1 & 2 & 4 & 8 \\
\hline$>3 \mathrm{rd}$ & 18 & 1 & 21 & 15 & 5 & 60 \\
\hline \multicolumn{7}{|l|}{ Source of Holiday Money } \\
\hline Personal Savings & 18 & 2 & 12 & 11 & 18 & 61 \\
\hline Assistance from friends/family & 2 & 0 & 20 & 7 & 6 & 35 \\
\hline Others & 0 & 0 & 0 & 1 & 3 & 4 \\
\hline Total & 20 & 2 & 32 & 19 & 27 & 100 \\
\hline
\end{tabular}

Source: The results of data processing (2017)

\section{Youth Travel Characteristics}

Based on the results of questionnaires to 100 respondents, youth travel who visited Ambon Island have a high motivation on value and culture, and social values. Most of respondents say strongly agree that they have the trip for values and cultures (mean 4.48). And the respondents says strongly agree that they have the trip for social value (mean 4.29).

The source of travel information majority from internet (45 respondents) and friends or family (54 respondents). Youth travel tend to arrange their travel independently (49 respondents) and with their friends or family 
respondents). Youth travel will make a trip when they get holiday from school or work (56 respondents) with the most popular time to travel are in December (22 respondents) and June (21 respondents).

The main trip driver of youth travel in Ambon Island is Outdoor attraction (74 respondents), such as relax on the beach $(18,80 \%)$.

The two highest interesting destinations of youth travel in Ambon Island are Pulau Pombo (8,90\%) and Pantai Liang (7,10\%). Majority of youth traveler (29 respondents) spend more than 12 days in Ambon Island.

The respondents prefer stay at night at friends and relatives residences during having the trip (69 respondents). It's followed by Guest House (12 respondents). The type of transportation used by young travelers to Ambon Island is airplane (46 respondents), ship (27 respondents). During in the destination youth travelers ride motorcycle (52 respondents).

\section{Youth Travel Pattern}

The travel pattern illustrates the structure and flow of travel from point of destination to other interconnected destinations. The travel pattern is usually depicted with a travel itinerary that addresses the activities of tourists. Based on the results of questionnaires to 100 respondents, youth travel who visited Ambon Island agree that Preferences and needs, interest or motivation, budget, and security are important factors to consider in creating an itinerary.

Table 3. Youth Travel Pattern in Ambon Island

\begin{tabular}{|c|c|c|c|c|c|c|c|}
\hline \multirow[t]{2}{*}{ Category } & \multirow[t]{2}{*}{ Item } & \multicolumn{5}{|c|}{ Origin } & \multirow[t]{2}{*}{ Total } \\
\hline & & $\begin{array}{l}\text { Maluku } \\
\text { Tengah }\end{array}$ & SBB & SBT & $\begin{array}{l}\text { Other Region } \\
\text { in Maluku }\end{array}$ & $\begin{array}{l}\text { Other City in } \\
\text { Indonesia }\end{array}$ & \\
\hline Travel & Single Point & 5 & 1 & 15 & 8 & 7 & 36 \\
\hline \multirow[t]{6}{*}{ Pattern } & Base Site & 3 & 1 & 3 & 4 & 5 & 16 \\
\hline & Stopover & 10 & 0 & 9 & 4 & 11 & 34 \\
\hline & Chaining Loop & 2 & 0 & 5 & 3 & 2 & 12 \\
\hline & Destination Region & 0 & 0 & 0 & 0 & 2 & 2 \\
\hline & Loop & & & & & & \\
\hline & Total & 20 & 2 & 32 & 19 & 27 & 100 \\
\hline
\end{tabular}

Source : The results of data processing (2017)

Based on the results from Table 3, there are 36 respondents use Single Point Pattern on their trip to Ambon island. Followed by 34 respondents use Stopover Pattern, 16 respondents use Base Site Pattern, 12 respondents use Chaining Loop Pattern and Destination Region Loop by 2 respondents.

The majority of respondents use Single Point Pattern. There are 13 tourist attractions that become the main tourist destination of respondents. The 13 
tourist attractions can be seen in Figure 2. Liang Beach is the most favorite tourist destination. It's chosen by 11 Respondents of 36 respondents.

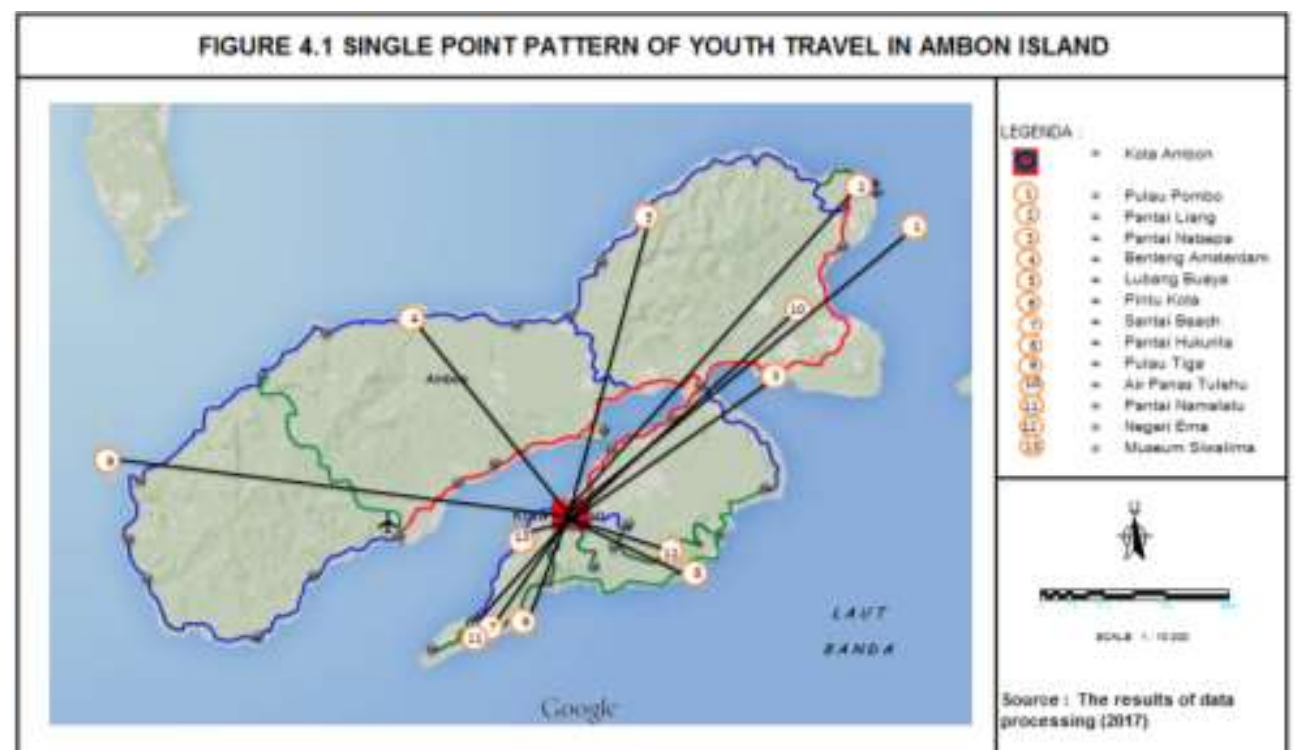

Figure 2. Single Point Pattern

Base Site Pattern is formed by 16 respondents with two most dominant route. There are Ambon City - Air Panas Tulehu - Rumah Pohon Desa Waii Pantai Batu Kuda and Ambon City - Pantai Pintu Kota - Pantai Namalatu. It's shown in Figure 3.

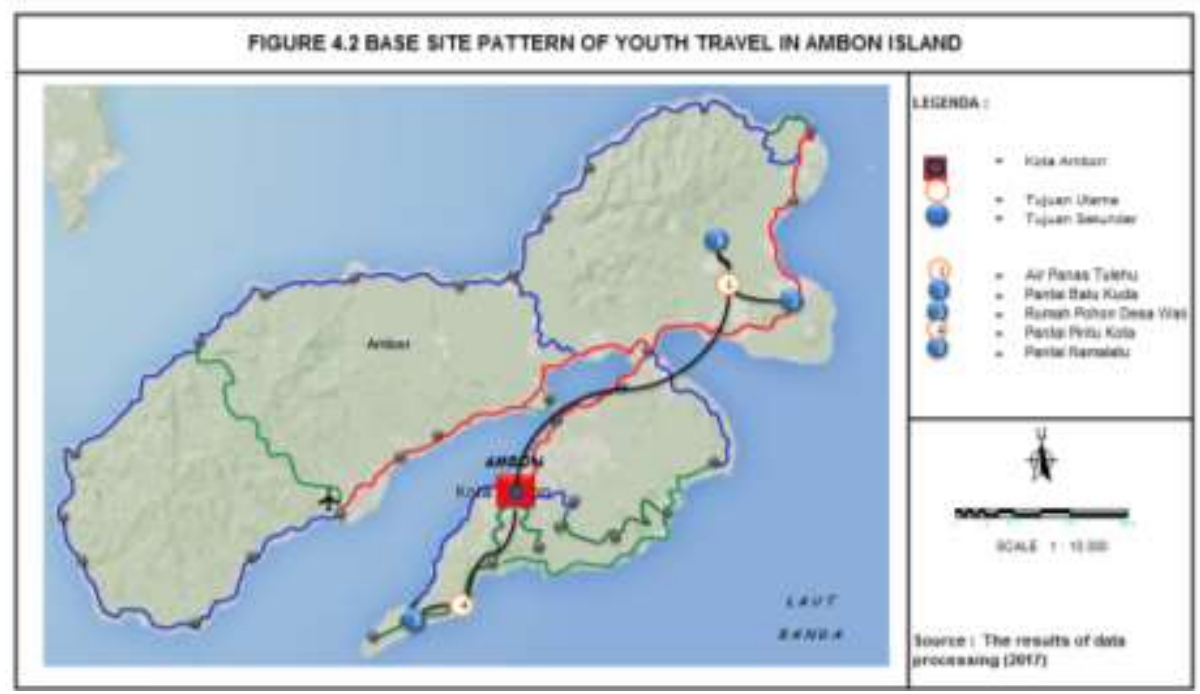

Figure 3. Base Site Pattern

TRJ Tourism Research Journal, Volume 1 (1), 2017 
Stopover pattern is formed by 34 Respondents with most dominant route. There are Kota Ambon - Pantai Natsepa - Air Panas Tulehu - Rumah Pohon Desa Waii - Pantai Liang and Kota Ambon - Batu Layar - Pulau Tiga. It's shown in Figure 4.

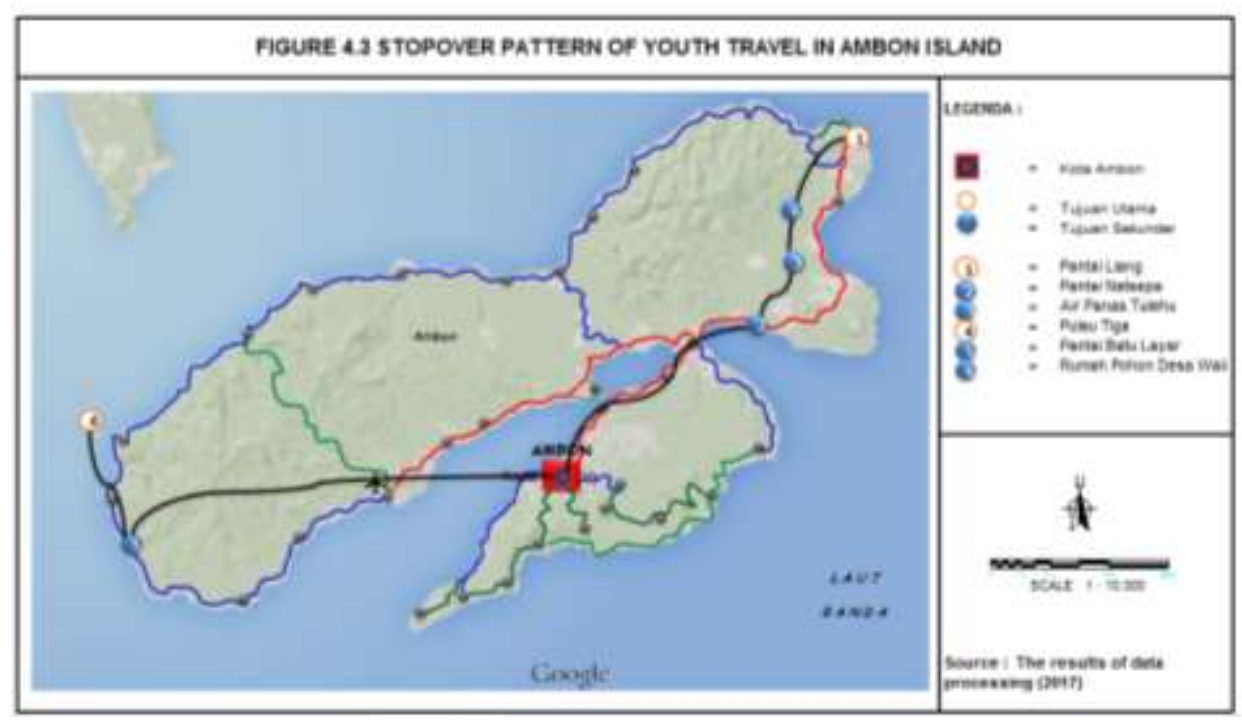

Figure 4. Stopover Pattern

Chaining Loop pattern is formed by 12 respondents with two most dominant routes. There are Kota Ambon - Pantai Natsepa - Pantai Liang Lubang Buaya then back to Kota Ambon and Kota Ambon - Batu Lubang Batu Layar - Benteng Amsterdam - Kota Ambon, shown in Figure 5.

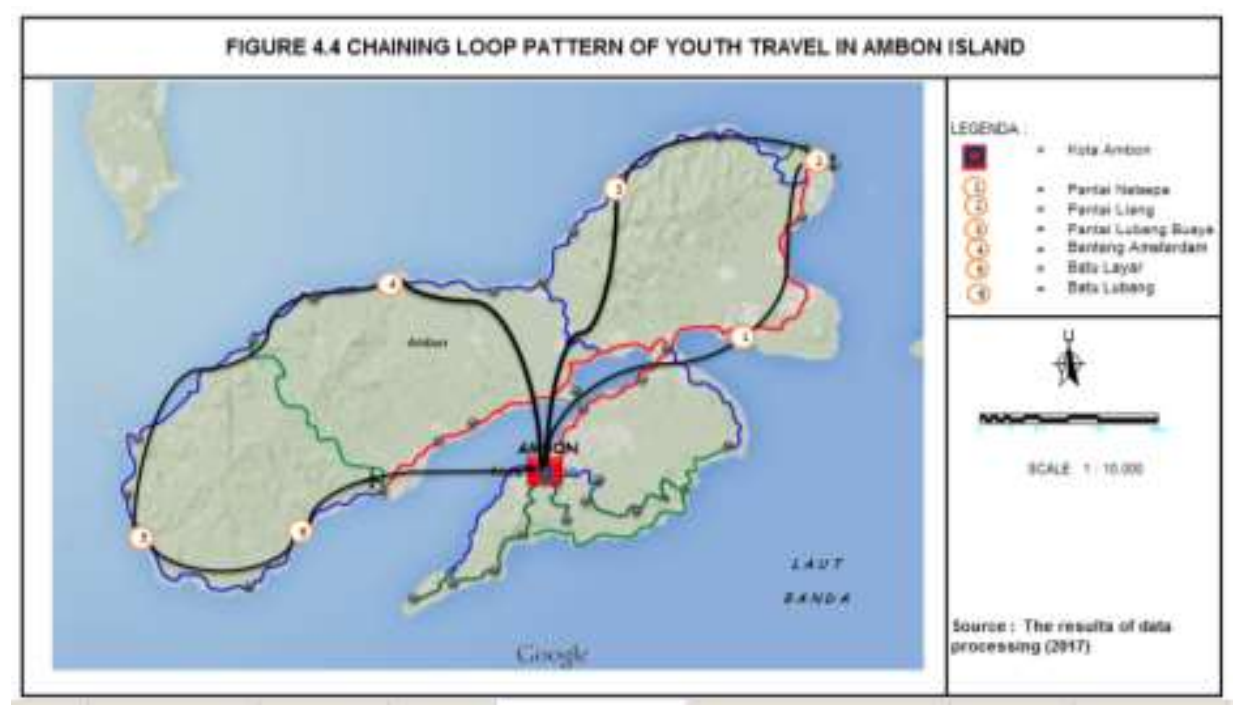

Figure 5. Chaining Loop Pattern

TRJ Tourism Research Journal, Volume 1 (1), 2017 
Destination Region Loop is formed by 2 respondents with the popular routes Kota Ambon - Air Panas Tulehu - Pantai Liang - Pantai Batu Lubang Benteng Amsterdam - Pantai Batu Layar- Pantai Hulua Wakasihu - Pantai Batu Lubang - Pantai Natsepa - Kota Ambon. It's shown in figure 6.

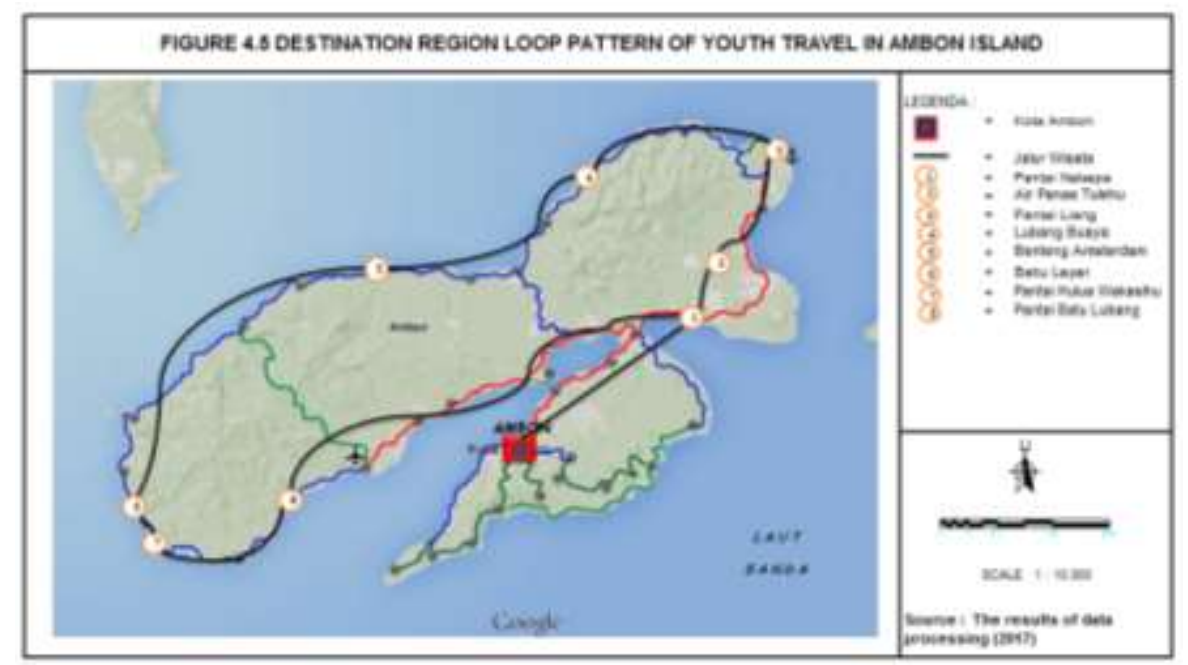

Figure 6. Destination Region Loop Pattern

In order to incrase the number of youth traveler in Ambon Island, all the stackholders need to improve the diversity of Travel Patterns product with cultural attractions, outdoors attractions, historical sites and building, culinary and the activities with local people. This study recommends 4 travel patterns for youth travel in Ambon Island. There are:

1. Travel Pattern I (Desa Batumerah-Pantai Natsepa).

2. Travel Pattern II (Desa Mamala-Desa Morella).

3. Travel Pattern III (Negeri Amahusu-Museum Siwalima-Batu Capeo).

4. Travel Pattern IV (Benteng Amsterdam-Masjid Tua Wapaue).

Travel Pattern I is described in Figure 7. It includes Desa Batumerah and Pantai Natsepa. 


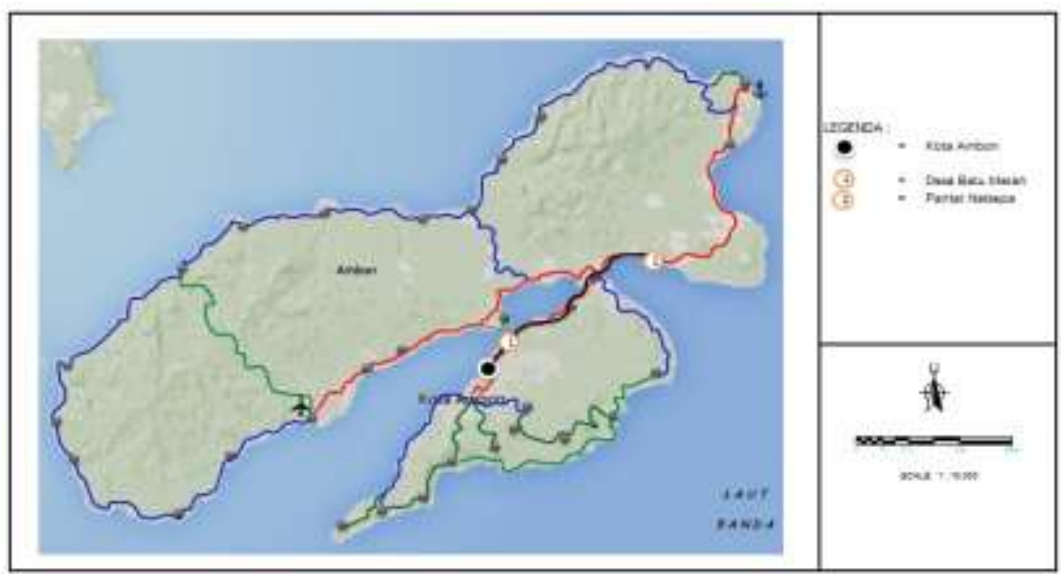

Figure 7. Travel Pattern I (Desa Batumerah-Pantai Natsepa)

Source : The results of data processing (2017)

Travel Pattern II is described in Figure 8. It consists of Desa Mamala and Desa Morella. It's shown in Figure 8.

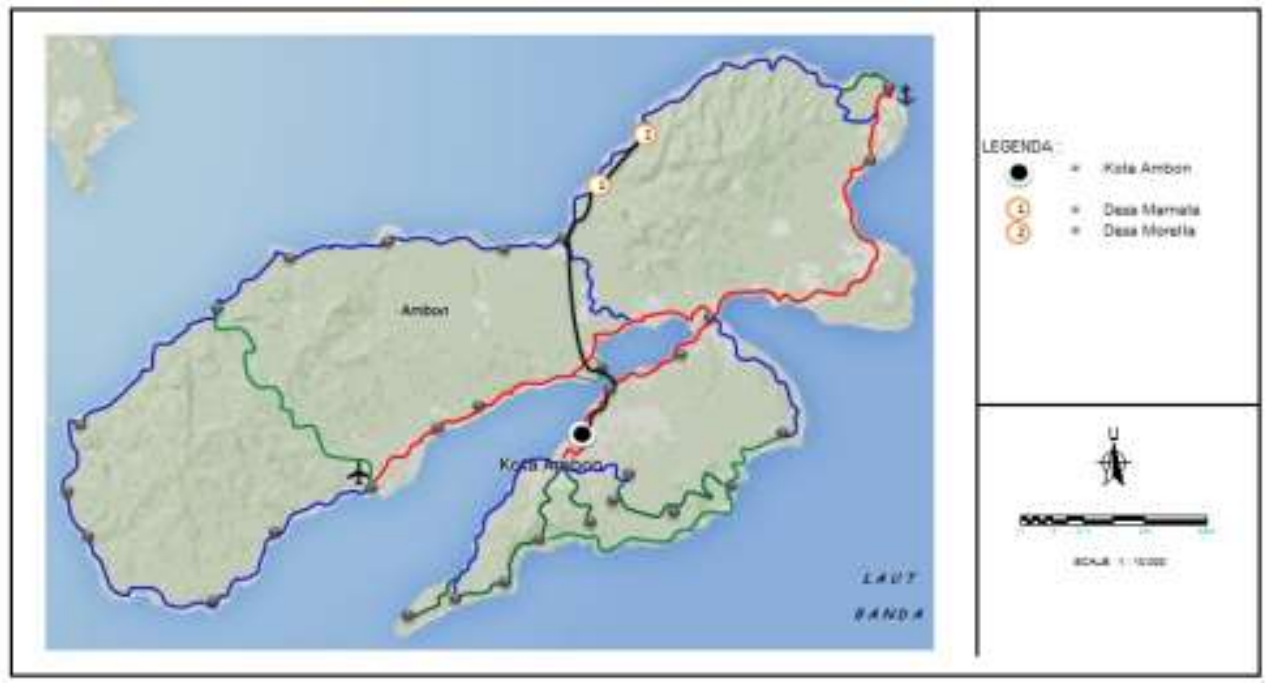

Figure 8. Travel Pattern II (Desa Mamala-Desa Morella)

Source: The results of data processing (2017)

Travel Pattern III includes Negeri Amahusu, Museum Siwalima, and Batu Capeo. It's shown in Figure 9. 


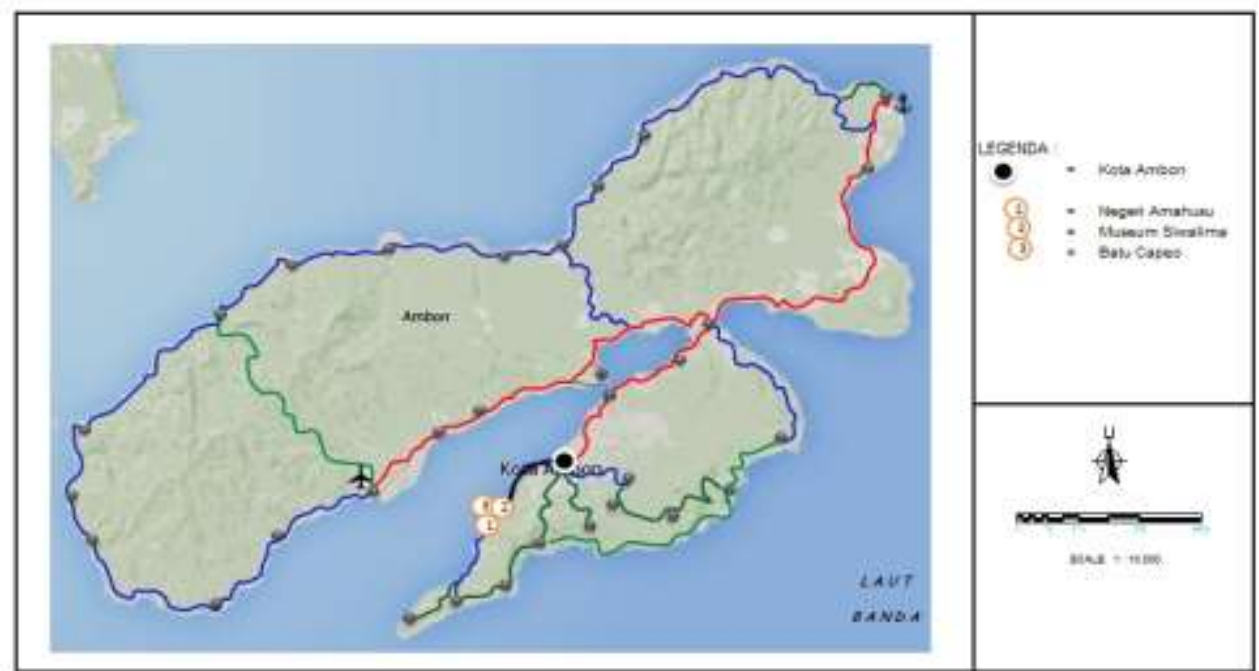

Figure 9. Travel Pattern III (Negeri Amahusu-Museum Siwalima-Batu Capeo)

Source : The results of data processing (2017)

Travel Pattern IV covers Benteng Amsterdam and Masjid Tua Wapaue. It's described in Figure 10.

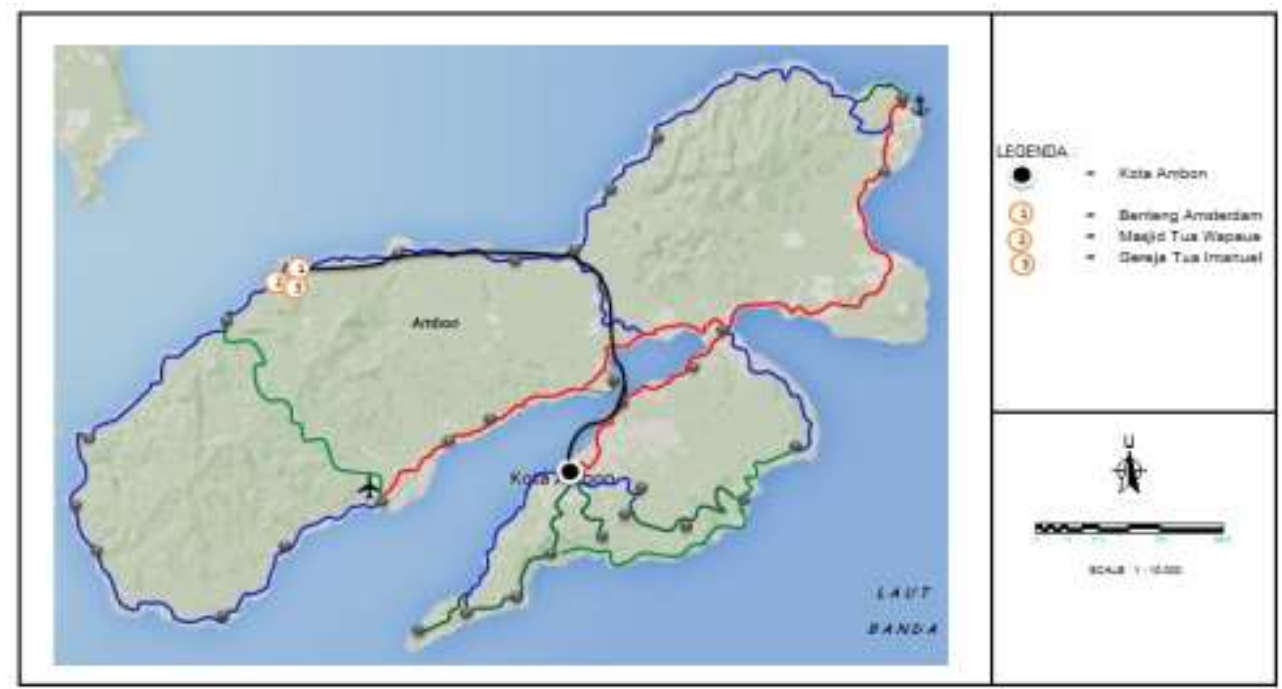

Figure 10. Travel Pattern IV (Benteng Amsterdam-Masjid Tua Wapaue)

Source: The results of data processing (2017)

\section{F. Conclusion}

The majority of youth travelers in Ambon Island are local tourist who came from the other region in Maluku Province. Respondents dominated by female youth travel, an increase in the number of female youth traveler has been shown also in the results of research conducted by Richard and Wilson (2003) who explain that the results of field observations and other studies show an 
increase in the proportion of female travelers. Male travelers tend to be older when compared with the average female traveler. The demographic results of these tourists can be an opportunity for the related industries to develop a tour package for female youth travelers.

The average young traveler who came to Ambon Island was between 23 26 years old and 19-22 years old. In general, tourists at the age between 23-26 years old who have not married yet have more free time. While tourists at the age between 19-22 years are students and college students who have spare time to travel during a school holiday. This needs to be a concern for the travel industry to respond appropriately how to create and promote tourism products that are appropriate for this age. Offering the right tourist product can provide its own value for young travelers to the destinations they visit and they tend to return to the destination (Kihara, 2015; Richards, 2007)

Youth traveler who use single point pattern is Psycosentric. This type of tourist is a loner tourists who do not have an adventurous spirit and tend to find a popular tourist spot. Youth traveler who uses multi trip pattern like Stopover, Base Site, Chaining Loop and Destination Region Loop tend to be allocentric tourist. This type of tourists are interested in various activities, confident and have an adventurous spirit that tends to try new things in order to satisfy their curiosity. (Butler in Rachman, 2014)

Based on the results of this study. Youth travel has been found to be very important to the future of tourism industry. The infromation from this study can be use as guidelines in developing the tourism industry in Ambon Island and Maluku Province. Travel industry can create combination between popular tourist destinations with cultural tourism destinations, history, culinary so as to attract tourists and can compete with other tourist destinations in Maluku such as Ora Beach and Banda Island. The travel industri marketers should be more active in providing tourism information and create awareness of youth travel to the tourist attractions in Ambon Island in order to increase the number of tourist. Strengthening the image of tourism destinations of Ambon Island with tagline that is easy to remember by youth travel like "Pesona Ambon Manise" and "Baronda Ambon". Planning and development of tourist attraction that is still less popular by improving the quality of the 4 elements of the Tourism Destination, Amenity (Accommodation, Restaurant, Tourist Information Center, Guides), Accesibility (Transport), Ancillary (Bank, Post Police, Clinic / Hospital). The development of tourist attraction is expected in a sustainable way so it can still be used in the future. Empowering the local community with socialization about tourism and assistance to local communities to further enhance the creativity in the field of tourism such as making local craft that can be a souvenir for youth travelers, especially female travelers. 


\section{REFERENCES}

Canadian Tourism Commission. (2015). Canada Milennial Domestic Travel Summary Report : Canada: CTC Research

Demeter, et al. (2015). Dynamics of the youth travel market on a global level. Bulletin of the Transilvania University of Braşov Series V: Economic Sciences, Vol. 8 (57), 1.

Education Bureau Hongkong. (2013). Tourism and Hospitality Studies Five tuned version. Hongkong.

Hu, Y \& Ritchie, J. (1993). Measuring destination attractiveness: a contextual approach. Journal of Travel Research, 32(20), 25-34.

Kihara, W. (2015). Youth Travel As A Potential Market Segment For Tourism Industry Among The Young Travelers In Nairobi, Kenya. Kenya ; Kenyatta University.

Lau and McKercher. (2006). Understanding tourist movement patterns in a destination: A GIS approach. Hongkong; The Hong Kong Polytechnic University.

Moisa, C. (2010). Aspects Of The Youth Travel Demand. Annales Universitas Apulensis-Series Oeconomica, 12(2).

Moisa, C. (2010). Flows on the youth travel market. 1 Decembrie 1918 University,Alba - Iulia. Romania.

Moisa, C. (2010). Factor influencing the evolution of youth travel. 1 Decembrie 1918 University, Alba - Iulia, Romania.

Moisa, C. (2010). The Distinctivness of the youth travel product . 1 Decembrie 1918 University, Alba - Iulia, Romania.

Rangkuti, F. (2016). Teknik membedah kasus bisnis analisis SWOT. Jakarta : PT.Gramedia Pustaka Utama.

Richards, G. (2007). New Horizons II - The Young Independent Traveller. Amsterdam: WYSE Travel Confederation.

Richards, G., and Wilson, J. (2005). Youth tourism: finally coming of age, In: Niche Tourism: Contemporary Issues, trends and Cases, pp. 39-45, M. Novelli. Oxford: Elsevier Butterworth-Heinemann.

Sugiarto, Hendratono, T., and Sudibyo, D. (2015). Metodologi penelitian bospitaliti dan pariwisata. Jakarta; Matana Publishing.

Suyitno. (2001). Perencanaan Wisata. Yogyakarta: Kanisius.

World Tourism Organization. (2011). Affilliate Members Global Reports, Volume Two-The power of youth travel. Madrid, UNWTO.

World Tourism Organization. (2008). Youth Travel Matters - Understanding the Global Phenomenon of Youth Travel. 